\title{
WATER QUALITY CHECKS ON RIVER ATUWARA, SOUTH-WEST NIGERIA
}

\author{
DAVID O. OMOLE ${ }^{1}$, ADEBANJI S. OGBIYE ${ }^{1}$,EZECHIEL O. LONGE 2 , IFE K. ADEWUMI ${ }^{3}$, \\ OLUGBENGA O. ELEMILE ${ }^{4} \&$ THEOPHILUS I. TENEBE ${ }^{1}$ \\ ${ }^{1}$ Department of Civil Engineering, Covenant University, Nigeria \\ ${ }^{2}$ Department of Civil \& Environmental Engineering, University of Lagos, Nigeria \\ ${ }^{3}$ Department of Civil Engineering, Niger Delta University, Bayelsa State, Nigeria \\ ${ }^{4}$ Department of Civil Engineering, Landmark University, Nigeria
}

\begin{abstract}
Some water-use practices taking place along River Atuwara are conflicting and detrimental to public health and the environment. The Ogun State Water Corporation (OGSWC), which has the responsibility of supplying piped water to residents and industrial firms, also withdraws raw water from River Atuwara. However, OGSWC has low capacity to meet demand, thus many residents' recourse to alternative water sources including withdrawing water from the river for domestic purposes. At the upstream section of River Atuwara, however, waste deposits from illegal discharges of effluent from industries and sewage collectors are made into the river. Water samples were obtained from the upstream point where wastes are deposited into the river as well as the downstream location where villagers draw the water. Chemical parameters tested for include heavy metals such as iron, zinc, lead, cadmium, copper, nickel, and chromium. Additionally, nitrate and nitrite were tested. Tested biological parameters include total coliform and total bacteria count while tested physical parameters include $\mathrm{pH}$, temperature, dissolved oxygen, total dissolved solids, total suspended solids, and turbidity. All parameters were determined using standard laboratory methods. The results were compared to the Nigerian standard for drinking water quality (NSDWQ). Results indicate that the water being consumed by the villagers is unfit for drinking as lead, nickel, nitrite, and total coliform exceeded the standard limit by $900 \%, 6,910 \%, 8,000 \%$, and $1,610 \%$ respectively. The researchers recommended that the government needs to protect the helpless villagers from industrial polluters by deploying appropriate law enforcement agents. Also, advocacy programs should be launched to educate villagers on dangers of ingesting raw water from River Atuwara. Also, methods for home treatment of identified pollutants from the river should be taught to the users. These measures are necessary to protect public health from a possible outbreak of epidemic.
\end{abstract}

Keywords: river, pollution, water quality standards, heavy metals, drinking water, public health, dissolved oxygen.

\section{INTRODUCTION}

Rivers around the world serve multiple purposes for mankind including reservoir for freshwater supply, drainage for flood, storage for aquatic food, environmental conservation of biodiversity, transportation, and ironically, sinks for municipal wastewater [1]-[3]. The latter anthropological activity degrades the environment and poses a threat to the earlier mentioned activities. In many developing countries, supply of potable piped water services by government is almost impossible and citizens rely on self-help for solutions [4]-[6]. One of such self-help is use of raw water from rivers, streams, and other surface water bodies [2]. This practice inevitably exposes users to a variety of problems that threaten public health [7]. River Atuwara in Ota, south-west Nigeria is one such river being used by thousands of people [7]-[9]. Uses of River Atuwara include sand quarrying by construction workers, domestic usage by residents, baptism by religious bodies, waste sink by industries, and water supply by the State Water Corporation [10]. The obvious importance of River Atuwara notwithstanding, government carries on its seldom business of withdrawing raw water for distribution to few privileged customers in Ota without adequate monitoring of stream quality 
or prevention of polluters from abusing the river. It is free for all along the river. This study therefore aims at conducting quality checks at two major points along the river - the point of pollution at the upstream (U/S) segment of the river by an alcohol manufacturing company's effluent and the point where villagers fetch water for domestic use, some 1.3 kilometers downstream $(\mathrm{D} / \mathrm{S})$ of the River. This was done without prejudice to the fact that some of the measured contaminants in the water could also have come from other polluting sources and even natural deposits in the environment. Therefore, the aim of this study is to identify pollutants that may adversely impact public health and comparison with standard limits as set by the national standards for drinking water quality [11].

\section{MATERIALS AND METHOD}

River Atuwara is a major river in Ota and the portion of the river that crosses Ota spans approximately 24 kilometers. The segment of the river that was selected for the study spans $1.3 \mathrm{~km}$ (Fig. 1). The selected U/S segment of the river was chosen because of the point source of an alcoholic beverage company that empties its effluent there and the downstream segment was selected because villagers draw water for domestic use. The point where the effluent sample was obtained is S21. The point where the effluent meets the river is S20. A lot of sand quarrying activity and other human traffic flow was observed at S10. The point where Ogun State Water Corporation (OGSWC) withdraws for supply is S5 and the point where villagers obtain water for drinking and other domestic use is S1. A road bridge crosses over River Atuwara just before S5. Water samples for laboratory analysis were obtained from points S1, S20 and S21. Physical parameters of the samples such as DO, temperature, $\mathrm{pH}$, and conductivity were determined in-situ using hand-held Hanna model HI2040 multi-meter. Other parameters were determined in the laboratory. Turbidity was determined using Hanna kit; total solid (TS), total suspended solids (TSS) and total dissolved solids (TDS) were determined using gravimetric method. All heavy metals (cadmium, lead, zinc, nickel, and iron) were determined using atomic absorption spectroscopy while nitrate and nitrite were determined using Hach UV screening model DR 6000 equipment. Total bacteria and total coliform were determined using spread plate technique. All samples meant for laboratory analysis were preserved at $4^{\circ} \mathrm{C}$ and transported to the Chemistry laboratory of the University of Lagos, Akoka, Yaba, Lagos State within three hours of the sampling exercise. All samples meant for chemical parameter determination were stored in 2-litre plastic bottles and those meant for biological parameter determination were stored in $500 \mathrm{ml}$ glass bottles which were hermetically sealed. The obtainable laboratory results were subsequently input to Microsoft Excel spread sheet for data storage and analysis. The Nigerian National Standard for Drinking Water Quality document [11] was used as guideline for comparing the state of pollution of the water samples obtained from River Atuwara.

\section{RESULTS AND DISCUSSION}

Results obtained from the laboratory are summarised in Table 1. Of all 21 quality parameters checked, the river water quality passed 15 parameters but failed six namely lead, nickel, DO, nitrite, total coliforms, and total bacteria tests.

\subsection{Lead}

Lead is a heavy metal that may adversely impact the public health when people are exposed to it, regardless of age, gender, or mode of exposure [12]. Lead, aside being a carcinogen, also impacts the central nervous system of the exposed individual and could lead to delayed 


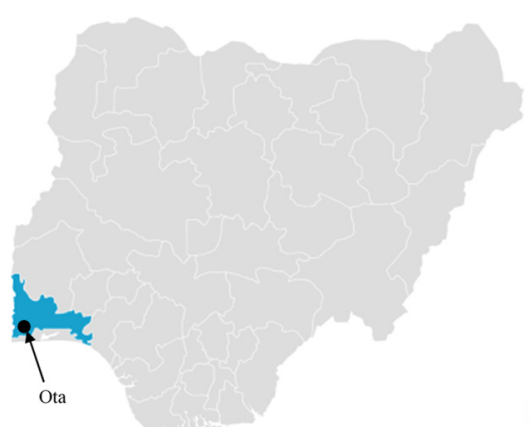

(a)

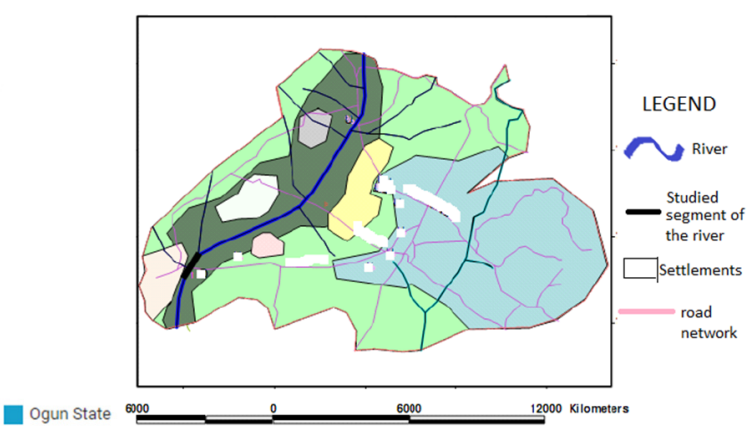

(b)

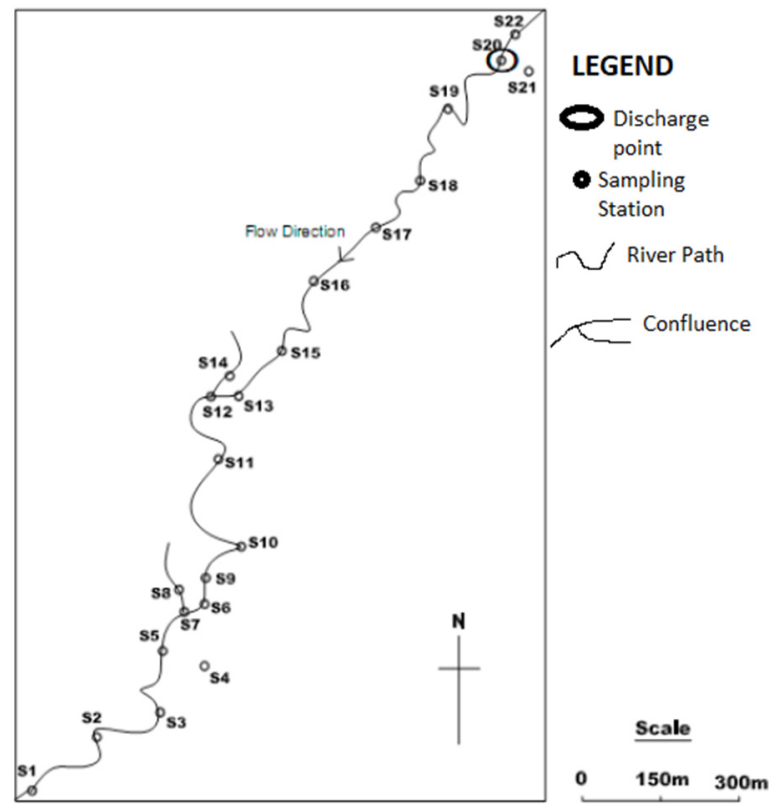

(c)

Figure 1: (a) Map of Ota in Ogun State, Nigeria; (b) Map of River Atuwara in Ota, Ogun State, Nigeria; (c) Studied segment of River Atuwara in Ogun State, Nigeria.

mental and physical growth in children and could affect the attention span and learning abilities of children [10], [12]. Fig. 2 shows that the lead content of the U/S and D/S segments of the river exceeded specified limits by 1,010 and $900 \%$ respectively. Lead is one of the contaminants found in the effluent sample from the alcoholic beverage company which impacted River Atuwara (Table 1). Lead reputably come from brewery, automobile industries, petroleum refining, agricultural chemicals, mechanical services, and paper mill industries [13]. Lead in the river may also have been released by the sand quarrying activity which may disturb natural deposits in the river bed [14]. Lead cannot be treated by disinfection or other simple methods and therefore makes it a highly dangerous metal to users of River Atuwara. 
Table 1: Results of river water and effluent sample.

\begin{tabular}{|c|c|c|c|c|c|}
\hline \multirow[b]{2}{*}{$\mathbf{s} / \mathbf{n}$} & \multirow[b]{2}{*}{ PARAMETER } & \multicolumn{3}{|c|}{ RESULT } & \multirow[b]{2}{*}{ NSDWQ } \\
\hline & & $\begin{array}{c}\text { S20 } \\
(\mathbf{U} / \mathbf{S})\end{array}$ & $\begin{array}{c}\text { S1 } \\
\text { (D/S) }\end{array}$ & $\begin{array}{c}\text { S21 } \\
\text { (Effluent) }\end{array}$ & \\
\hline 1 & Temperature $\left({ }^{\circ} \mathrm{C}\right)$ & 28.6 & 28.8 & $\mathrm{NT}^{*}$ & $22-30$ \\
\hline 2 & $\mathrm{pH}$ & 6.821 & 6.792 & 5.689 & $6.8-8.5$ \\
\hline 3 & Turbidity (NTU) & 0.01 & 0.05 & NT & 5 \\
\hline 4 & Conductivity (us/cm) & 76 & 85 & NT & 1,000 \\
\hline 5 & Total solids (mg/l) & 0.2 & 0.178 & NT & 1,200 \\
\hline 6 & Total suspended solids (mg/l) & 0.03 & 0.118 & 0.012 & - \\
\hline 7 & Total dissolved solids (mg/l) & 0.17 & 0.06 & 0.18 & 500 \\
\hline 8 & Dissolved oxygen $(\mathrm{mg} / \mathrm{l})$ & 2.4 & 3.4 & 0.7 & 7.8 \\
\hline 9 & $\mathrm{COD}(\mathrm{mg} / \mathrm{l})$ & 3.4 & 2.8 & 0.4 & - \\
\hline 10 & Chloride (mg/l) & 49.63 & 56.72 & & 250 \\
\hline 11 & Nitrate $(\mathrm{mg} / \mathrm{l})$ & 22.5 & 3.4 & 15.8 & 50 \\
\hline 12 & Nitrite (mg/l) & 17 & 16 & NT & 0.2 \\
\hline 13 & Copper (mg/l) & 0.3 & 0.18 & NT & 1 \\
\hline 14 & $\operatorname{Iron}(\mathrm{mg} / \mathrm{l})$ & 0.008 & 0.014 & 0.046 & 0.3 \\
\hline 15 & Zinc $(\mathrm{mg} / \mathrm{l})$ & 1.462 & 1.396 & 1.471 & 3 \\
\hline 16 & Lead (mg/l) & 0.101 & 0.09 & 0.114 & 0.01 \\
\hline 17 & Cadmium (mg/l) & ND** & ND & ND & 0.003 \\
\hline 18 & Nickel (mg/l) & 1.181 & 1.382 & 1.702 & 0.02 \\
\hline 19 & Chromium (mg/l) & ND & 0.014 & 0.02 & 0.05 \\
\hline 20 & Total bacterial count $(\mathrm{cfu} / 100 \mathrm{ml})$ & $2.20 \times 10^{6}$ & $2.24 \times 10^{6}$ & NT & - \\
\hline 21 & Total Coliform $(\mathrm{cfu} / 100 \mathrm{ml})$ & $1.0 \times 10^{3}$ & $1.6 \times 10^{6}$ & NT & $0-10$ \\
\hline
\end{tabular}

*NT $=$ Not tested; $* * \mathrm{ND}=$ Not detected.

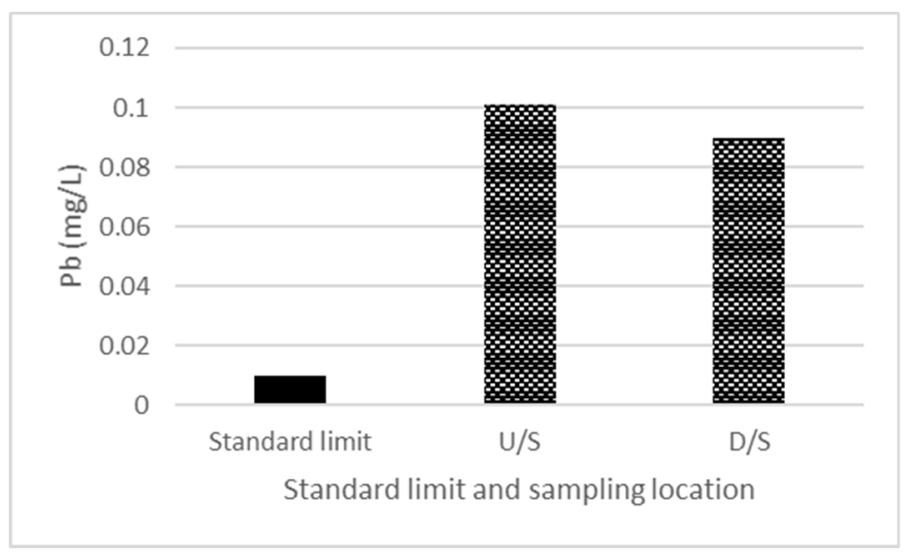

Figure 2: Lead in the water samples. 


\subsection{Nickel}

Nickel, an abundant element in nature, is also a metal that could adversely affect persons exposed to it. Nickel affects the cardiovascular system, human skin, as well as respiratory and immune systems in humans [15]. Like Lead, Nickel could be found in sea or river beds and released by disturbances [14], [15]. Similarly, nickel could originate from automobile and agro-chemical industries [13]. Nickel also dissolves easily and combines with other elements such as chlorine, sulphur, oxygen, iron, copper, chromium and zinc [15]. The Nickel concentration found in the S20 and S1 samples from River Atuwara indicate that the metal exceeded the prescribed limit by 5,905 and 6,910\% respectively (Fig. 3). This concentration is high and detrimental to public health.

\subsection{Dissolved oxygen}

When there is no contamination whatsoever in a river system, dissolved oxygen (DO) content of the river is expected to be at saturation level, depending on temperature [10]. At the average sampling temperature of $28.7^{\circ} \mathrm{C}$, the DO at saturation for the river was expected to

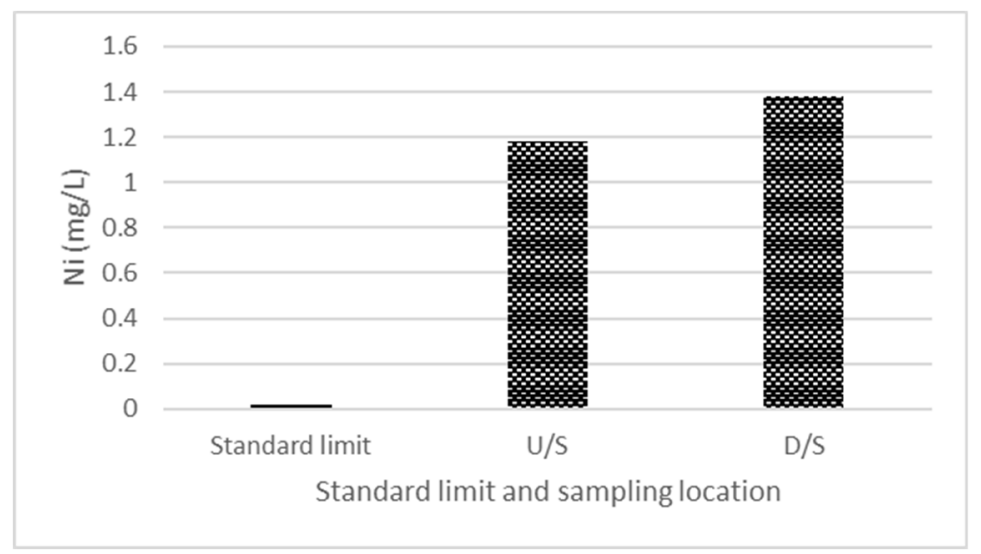

Figure 3: Nickel in the water samples.

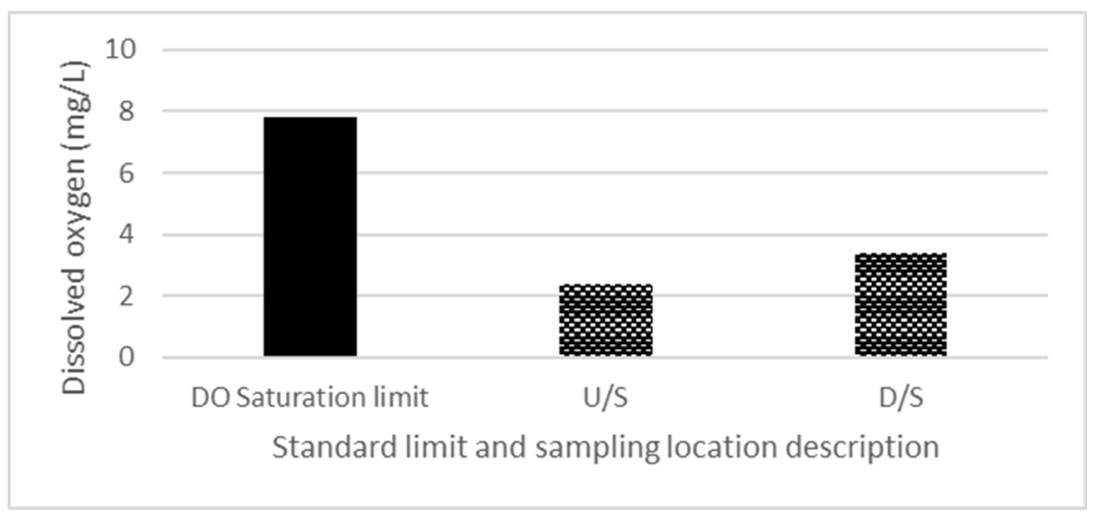

Figure 4: DO content in the water samples. 
be $7.8 \mathrm{mg} / \mathrm{L}$. However, it was well below saturation at both the U/S and D/S portions of the river, thereby indicating that there may be biochemical or chemical oxygen demanding substances in the river (Fig. 4).

\subsection{Nitrite}

Nitrite is an indication that organic substances are present in water or waste samples. It is a dangerous compound that could cause cyanosis and asphyxiation in children [10], [11]. It is a compound that is associated with sewage and other decomposing substances [16]. A highly unstable compound, it uses up oxygen to break down to nitrate, thus its tendency to asphyxiate infants when ingested. The nitrite content found in the water samples from the $\mathrm{U} / \mathrm{S}$ and $\mathrm{D} / \mathrm{S}$ segments of the river were higher than the SON standard limit by 8,500 and $8,000 \%$ respectively (Fig. 5). Nitrite is commonly treated in water and wastewater by bacterial or chemical reactions [13].

\subsection{Total Coliform}

Total Coliform is classified as a thermotolerant bacteria that occurs in sewage and natural waters but can easily be removed by disinfection [16]. The measure of Total Coliform found at the upstream (S20) and downstream (S1) section of the river exceeded specified standard [11] by 10,000 and $1,600 \%$ respectively (Fig. 6). Although it can be said that the concentration of total coliform at the U/S section of the river had been attenuated downstream, the total coliform content at $\mathrm{S} 1$ where residents draw water for domestic makes the water unfit for consumption.

\subsection{Total bacteria}

The US Environmental Protection agency specifies that total bacteria (which may also be interpreted as total microbial (aerobic) count [17]), should not exceed 500cfu/100ml. However, Fig. 7 indicates that water samples from both the U/S and D/S sections of the river exceeded the limit by $440,000 \%$ and $448,000 \%$ respectively.

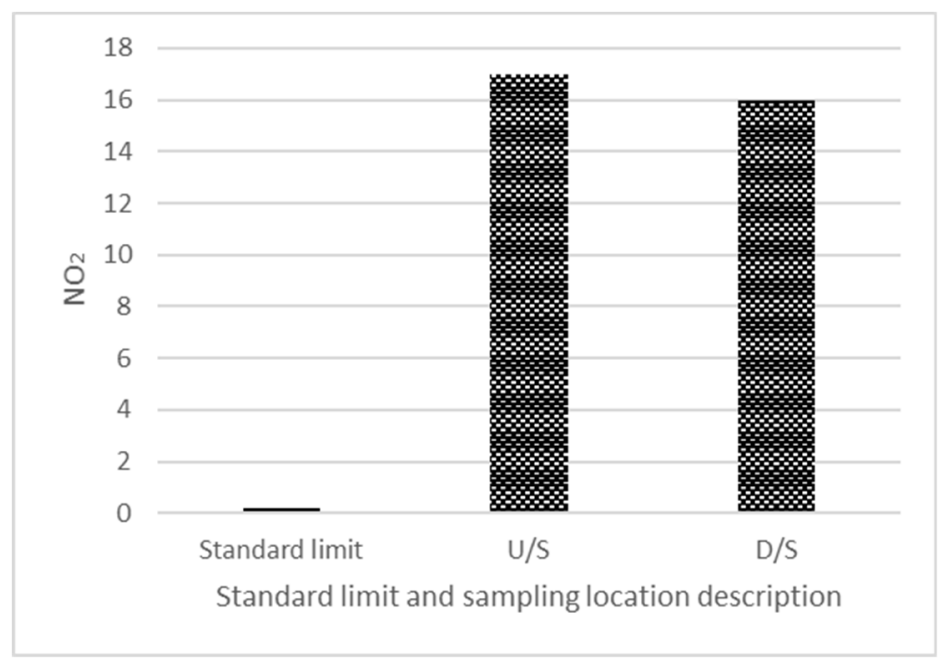

Figure 5: DO content in the water samples. 


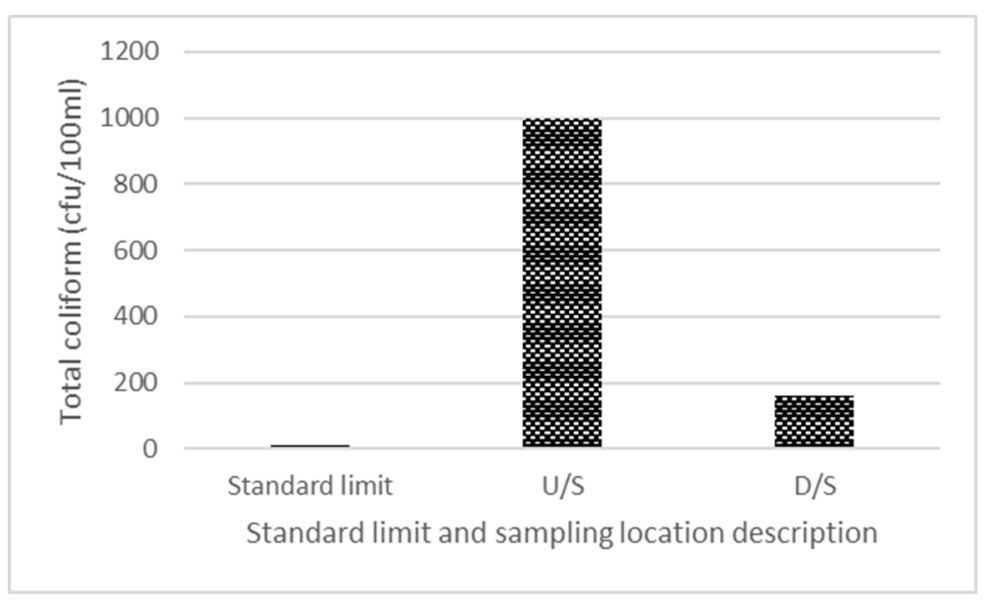

Figure 6: Total Coliform in the water samples.

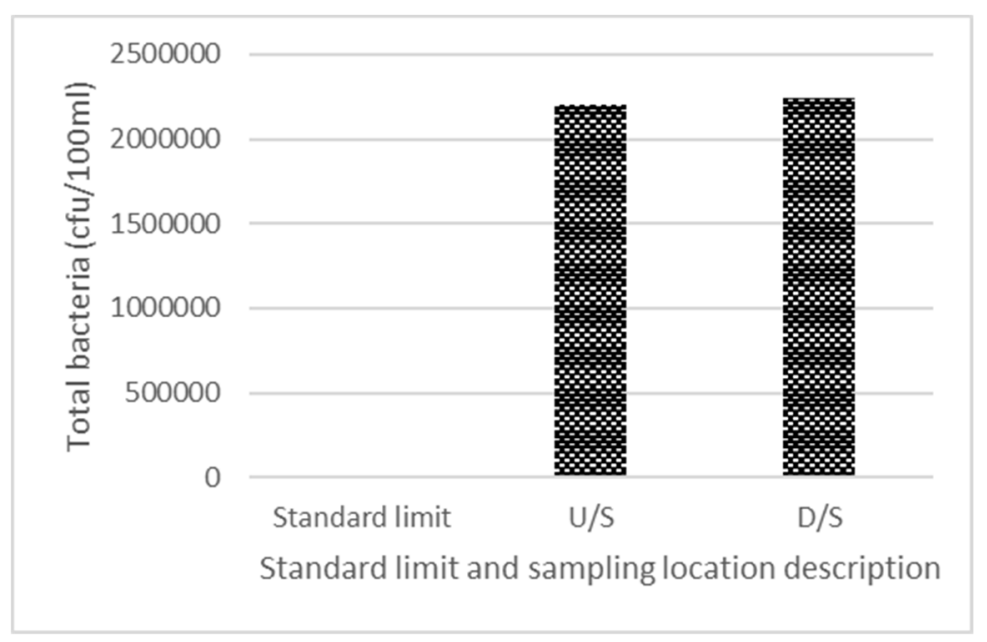

Figure 7: Total bacteria in the water samples.

\section{CONCLUSION AND RECOMMENDATION}

The study deduced from the analysis of water samples obtained from River Atuwara that public health was in jeopardy because of the toxic and dangerous substances found in them. It is therefore recommended that users should be advised to desist from consuming raw water from the river. Due to the presence of nickel in the water as well, recreational activities such as swimming should also be discouraged since the commonest manifestation of the metal is allergic dermatitis [16]. Restricting people from using water from the river, however, places people in a dilemma given that piped water services to the vast majority of residents is virtually absent [4]. Therefore, government should, at the least, curb the dangerous practice of discharging harmful effluent into the environment without adequate pre-treatment by deploying appropriate law enforcement agencies. It is also recommended that information on the presence of contamination in the river as well as varying home treatment methods should 
be given to villagers through advocacy programs. Also, non-governmental agencies should be encouraged to donate clean water sources such as dug wells (bore-holes) for the community's use.

\section{ACKNOWLEDGEMENT}

The authors appreciate the management of Covenant University for supporting this research and for sponsorship to the WIT conference.

\section{REFERENCES}

[1] Ngene, B.U., Tenebe, I.T., Emenike, P.C. \& Airiofolo, R.I., Statistical evaluation of hydro-meteorological data: A case study of Ishiagu in South-East Zone Nigeria. ARPN Journal of Engineering and Applied Sciences, 10(18), pp. 8192-8199, 2015.

[2] Omole, D.O., Badejo, A.A., Ndambuki, J.M., Musa, A.G. \& Kupolati, W.K., Analysis of auto-purification response of the Apies River, Gauteng, South Africa, to treated wastewater effluent. Water $S A, \mathbf{4 2}(2)$, p. 225, 2016. doi: 10.4314/wsa.v42i2.06.

[3] Abia, A.L.K., Ubomba-Jaswa, E. \& Momba, M.N.B., Impact of seasonal variation on Escherichia coli concentrations in the riverbed sediments in the Apies River, South Africa. Science of the Total Environment, 537, pp. 462-469, 2015. doi: 10.1016/ j.scitotenv.2015.07.132.

[4] Omole, D.O., Ndambuki, J.M. \& Osabuohien, E., Nigeria's Legal Instruments for Land and Water Use: Implications for National Development, ed. E. Osabuohien, IGI Global, 2014. doi: 10.4018/978-1-4666-7405-9.ch01810.4018/978-1-4666-7405-9. ch018.

[5] Omole, D.O., Ndambuki, J.M., Badejo, A.A., Oyewo, D.O. \& Soyemi, T.O., Public feedback on state of domestic water supply in Lagos: Implications for public health. Indian Journal of Traditional Knowledge, 15(2), 2016.

[6] Emenike, P.C., Tenebe, T.I., Omeje, M. \& Osinubi, D.S., Health risk assessment of heavy metal variability in sachet water sold in Ado-Odo Ota, South-Western Nigeria. Environmental Monitoring and Assessment, 189(9), p. 480, 2017. doi: 10.1007/ s10661-017-6180-3.

[7] Omole, D.O., Ndambuki, J.M., Nwafor-Oritzu, C.A. \& Obata, C.E., Development of a water treatment plant for heavy metal adsorption. Proceedings of the IASTED International Conference on Environment and Water Resource Management, Africa EWRM 2014, pp. 1-5, 2014. doi: 10.2316/P.2014.812-002.

[8] Omole, D.O. \& Longe, E.O., Re-aeration coefficient modeling: A case study of River Atuwara in Nigeria. Research Journal of Applied Sciences, Engineering and Technology, 4(10), 2012.

[9] Omole, D.O., Longe, E.O. \& Musa, A.G., An approach to reaeration coefficient modeling in local surface water quality monitoring. Environmental Modeling and Assessment, 18(1), 2013. doi: 10.1007/s10666-012-9328-010.1007/s10666-0129328-0.

[10] Omole, D.O., Reaeration Coefficient Modelling: Case study of River Atuwara, Ota, Nigeria - Covenant University Repository, LAP Lambert Academic Publishing GmbH \& Co. KG: Saarbrücken, Germany, 2011.

[11] Standards Organization of Nigeria. Nigerian Standard for Drinking Water Quality, Abuja, Nigeria, 2007.

[12] ASTDR, Lead $(\mathrm{Pb})$ Toxicity: what are the physiologic effects of lead exposure? ATSDR - Environmental Medicine \& amp; Environmental Health Education - CSEM. Env health and Medicine - Agency for Toxic Substances and Disease Registry, 2017, 
Online. https://www.atsdr.cdc.gov/csem/csem.asp?csem=34\&po=10. Accessed on: 27 Nov. 2017.

[13] FEPA, Interim Guidelines and Standards for Industrial Effluent, Gaseous Emmisions and Noise Limitations, pp. 1-250, 1991.

[14] Glynn, P.D. \& Plummer, L.N., Geochemistry and the understanding of ground-water systems. Hydrogeology Journal, 13(1), pp. 263-287, 2005.

[15] ATSDR, Toxic Substances - Nickel. Toxic Substances Portal, 2011. www.atsdr.cdc.gov/substances/toxsubstance.asp?toxid=44. Accessed on: 4 Dec. 2017.

[16] WHO, Guidelines for Drinking Water Quality, p. 631, 2017.

[17] Edstrom Indutries, Drinking Water Quality Standards, Waterford: Winsconsin, 2003. 